\title{
c-Met is expressed by highly autoreactive encephalitogenic CD8+ cells
}

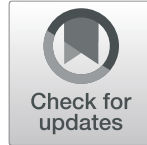

Mahdia Benkhoucha ${ }^{1} \mathbb{D}$, Isis Senoner ${ }^{1}$ and Patrice H. Lalive ${ }^{1,2^{*}}$

\begin{abstract}
Background: $\mathrm{CD} 8^{+} \mathrm{T}$ lymphocytes are critical mediators of neuroinflammatory diseases. Understanding the mechanisms that govern the function of this T cell population is crucial to better understanding central nervous system autoimmune disease pathology. We recently identified a novel population of highly cytotoxic c-Met-expressing $\mathrm{CD}^{+} \mathrm{T}$ lymphocytes and found that hepatocyte growth factor (HGF) limits effective murine cytotoxic $T$ cell responses in cancer models. Here, we examined the role of c-Met-expressing $\mathrm{CD}^{+} \mathrm{T}$ cells by using a $\mathrm{MOG}_{35-55} \mathrm{~T}$ cell-mediated EAE model.

Methods: Mice were subcutaneously immunized with myelin oligodendrocyte glycoprotein peptide $(\mathrm{MOG})_{35-55}$ in complete Freund's adjuvant (CFA). Peripheral and CNS inflammation was evaluated at peak disease and chronic phase, and c-Met expression by CD8 was evaluated by flow cytometry and immunofluorescence. Molecular, cellular, and killing function analysis were performed by real-time PCR, ELISA, flow cytometry, and killing assay.

Results: In the present study, we observed that a fraction of murine effector $C D 8^{+} T$ cells expressed c-Met receptor $\left(\mathrm{c}-\mathrm{Met}^{+} \mathrm{CD}^{+}\right)$in an experimental autoimmune encephalitis (EAE) model. Phenotypic and functional analysis of $\mathrm{c}-\mathrm{Met}^{+} \mathrm{CD}^{+} \mathrm{T}$ cells revealed that they recognize the encephalitogenic epitope myelin oligodendrocyte glycoprotein ${ }_{37-50}$. We demonstrated that this T cell population produces higher levels of interferon- $\gamma$ and granzyme $B$ ex vivo and that HGF directly restrains the cytolytic function of c-Met ${ }^{+} \mathrm{CD} 8^{+} \mathrm{T}$ cells in cell-mediated cytotoxicity reactions
\end{abstract}

Conclusions: Altogether, our findings suggest that the HGF/c-Met pathway could be exploited to modulate CD8 ${ }^{+} \mathrm{T}$ cell-mediated neuroinflammation.

Keywords: HGF, c-Met, CD8 ${ }^{+}$T cell, Neuroinflammation, EAE, MS

\section{Introduction}

The prevailing opinion is that multiple sclerosis (MS) is a CD4 $\mathrm{T}$ cell-mediated disease. However, many indicators imply a role for $\mathrm{CD}^{+} \mathrm{T}$ cells in MS pathophysiology, including their presence in a greater number than $\mathrm{CD} 4^{+} \mathrm{T}$ cells in MS-related brain lesions and a demonstration of direct axonal toxicity [1-6]. The exact role of $\mathrm{CD}^{+} \mathrm{T}$ lymphocytes in autoimmune central nervous system (CNS) inflammation remains controversial, and some evidence supports both pathogenic and protective roles for these cells in MS and in experimental autoimmune encephalomyelitis (EAE). In favor of the pathogenic contribution of $\mathrm{CD}^{+} \mathrm{T}$ lymphocytes,

\footnotetext{
* Correspondence: patrice.lalive@hcuge.ch

${ }^{1}$ Department of Pathology and Immunology, Faculty of Medicine, University of Geneva, Geneva, Switzerland

${ }^{2}$ Department of Neurosciences, Division of Neurology, University Hospital of Geneva, Geneva, Switzerland
}

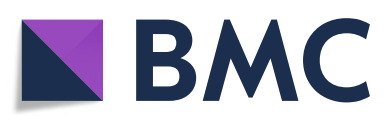

(c) The Author(s). 2020 Open Access This article is distributed under the terms of the Creative Commons Attribution 4.0 International License (http://creativecommons.org/licenses/by/4.0/), which permits unrestricted use, distribution, and reproduction in any medium, provided you give appropriate credit to the original author(s) and the source, provide a link to the Creative Commons license, and indicate if changes were made. The Creative Commons Public Domain Dedication waiver (http://creativecommons.org/publicdomain/zero/1.0/) applies to the data made available in this article, unless otherwise stated. demyelinated MS tissue [4], suggesting CNS antigen (Ag) reactivity and $\mathrm{CD}^{+} \mathrm{T}$ cells dependent lytic functions. $\mathrm{CD}^{+} \mathrm{T}$ cells also have been found in close association with demyelinated axons in MS brain tissue [7] and interact with neural cells [8]. Other groups have developed various models of $\mathrm{CD}^{+} \mathrm{T}$ lymphocyte-dependent EAE-like disease [9-13]. These models include pathogenesis induction by transfer of myelin basic protein ${ }_{79-87}$ or myelin oligodendrocyte glycoprotein (MOG) $35-55^{-}$-specific $\mathrm{CD}^{+} \mathrm{T}$ lymphocytes in $\mathrm{C} 3 \mathrm{H}$ and in C57BL/6 or RAG1/animals, through the use of MHC tetramer technology. The characterization of $\mathrm{MOG}_{35}$-55-specific $\mathrm{CD}^{+} \mathrm{T}$ cells throughout EAE progression showed that these cells are generated in $\mathrm{MOG}_{35-55}$-induced EAE mice in vivo and that $\mathrm{MOG}_{37-50}$ retains the full ability to stimulate MOG-specific $\mathrm{CD}^{+} \mathrm{T}$ cells in vitro [14]. 
Several reports describe a role for encephalitogenic $\mathrm{CD}^{+} \mathrm{T}$ cells in EAE. A protocol using extracellular vesicle fibrinogen administered to mice with EAE at peak clinical disease resulted in a unique spontaneous phenotype of relapsing-remitting disease, a clinical feature not generally observed in this $\mathrm{MOG}_{35-55} \mathrm{EAE}$ mouse model [15]. In addition, $\mathrm{CD} 8^{+} \mathrm{T}$ cells can mediate demyelination and oligodendrocyte toxicity through secretion of toxic factors, such as lymphotoxin [16, 17]. Human and mouse $\mathrm{CD} 8^{+} \mathrm{T}$ lymphocytes detected in the inflamed CNS compartment are predominantly $\mathrm{CD}_{62} \mathrm{~L}^{-}$ CCR7 $^{-}$effector memory lymphocytes. Compared to noneffector memory cells, these cells have a greater propensity to migrate across the human blood-brain barrier. In EAE, $\mathrm{CD}^{+} \mathrm{T}$ lymphocytes infiltrating the CNS display more aggressive functions (granzyme $\mathrm{B}^{+}$interferon $\left[\right.$ IFN]- $\gamma^{\text {hi }}$ ) than do CD4 ${ }^{+}$T lymphocytes [18].

Conversely, other studies have suggested a protective role for $\mathrm{CD}^{+} \mathrm{T}$ cells in both EAE and MS $[19,20]$. $\mathrm{CD}^{+} \mathrm{T}$ lymphocytes can modulate the phenotype of $\mathrm{CD}^{+} \mathrm{T}$ lymphocytes in the periphery of EAE mice by increasing Th2 cells [21]. In a myelin basic proteininduced EAE model, $\mathrm{CD}^{+} \mathrm{T}$ lymphocytes downregulated pathogenic myelin basic protein-reactive $\mathrm{CD} 4^{+} \mathrm{T}$ lymphocyte clones [22]. In addition, the transfer of $\mathrm{MOG}_{35-55^{-}}$-specific $\mathrm{CD}^{+} \mathrm{T}$ lymphocytes in mice suppresses the induction of EAE and inhibits ongoing EAE by a cytotoxic/suppressor mechanism [23, 24]. Therefore, the precise contribution of $\mathrm{CD}^{+} \mathrm{T}$ lymphocytes to the pathology of EAE and MS remains unclear.

The hepatocyte growth factor (HGF)/c-Met axis modulates several inflammatory-mediated diseases by acting on a wide variety of cells [25], including in EAE [26, 27]. Recent reports have stressed the multiple anti-inflammatory effects of HGF, including a Th2/Th3 bystander deviation with increased transforming growth factor (TGF)- $\beta 1$ and interleukin (IL)-10 [28, 29] and inhibition of Agpresenting cell (APC) function [26, 28, 30, 31]. HGF may also contribute to the expansion of myeloid-derived suppressor cells, which are potent $\mathrm{T}$ cell suppressors [32]. All of these effects could contribute to the protective action of HGF in EAE and/or MS either individually or collectively.

We recently found that a fraction of murine cytotoxic lymphocytes (CTLs) expresses c-Met (c-Met ${ }^{+}$CTLs). Functional and phenotypic analysis of this newly identified CTL population showed that $\mathrm{c}-\mathrm{Met}^{+}$CTLs display augmented cytolytic activities compared to their c-Met ${ }^{-} \mathrm{CTL}$ counterparts. Using cell-mediated cytotoxicity reactions in vitro and in vivo, we demonstrated also that the c-Met receptor ligand $\mathrm{HGF}$ can directly negatively regulate c$\mathrm{Met}^{+}$CTL cytolytic function in a cancer model [33].

In this study, we examined the role of c-Metexpressing $\mathrm{CD}^{+} \mathrm{T}$ cells by using a $\mathrm{MOG}_{35-55} \mathrm{~T}$ cell- mediated EAE model. Our aim was to complement previous studies of the function of the HGF/c-Met pathway in "conventional" $\mathrm{CD}_{4}^{+} \mathrm{T}$ cell-mediated demyelination $[26,34]$. We found that a subpopulation of effector $\mathrm{CD}^{+} \mathrm{T}$ cells expresses c-Met in EAE. In addition, our results offer a phenotypic and functional characterization of this population ex vivo and in vitro. We also examined the capacity of the c-Met ligand HGF to modulate c-Met-expressing $\mathrm{CD}^{+} \mathrm{T}$ cell function. Our findings suggest that c-Met expression by $\mathrm{CD}^{+} \mathrm{T}$ cells confers specific pro-inflammatory properties in $\mathrm{MOG}_{35-55}$-induced EAE.

\section{Materials and methods}

Mice

C57BL/6 J $\left(\mathrm{H}-2^{\mathrm{b}}\right)$ female mice were purchased from Charles River (France). Animals were housed in a specific pathogen-free barrier facility at the Medical Center of Geneva, Faculty of Medicine (Geneva, Switzerland). All experimental protocols and procedures were reviewed and approved by the Institutional Animal Care and Use Committee of the Geneva University School of Medicine. Animal care and experimental procedures were carried out in accordance with the guidelines of the Institutional Animal Care and Use Committee of the Geneva University School of Medicine.

\section{Induction and assessment of EAE}

Ten mice were immunized subcutaneously in the flanks with $200 \mu \mathrm{g} \mathrm{MOG}_{35-55}$ peptide (MEVGWYRSPFSRVVHLYRNGK; Anawa Trading) in complete CFA (DIFCO Laboratories), and $300 \mathrm{ng}$ pertussis toxin (Sigma-Aldrich) in phosphate-buffered saline (PBS) was administered intravenously on days 0 and 2 . Individual animals were observed daily, and clinical scores were assessed with a $0-5$ point scoring system as follows: $0=$ no clinical disease, $1=$ loss of tail tone only, $2=$ mild monoparesis or paraparesis, $3=$ severe paraparesis, $4=$ paraplegia and/or quadraparesis, and $5=$ moribund or death. Mice exceeding 2 days with a score of 3.5 were euthanized immediately. All analyses were performed on mice at peak disease reaching an EAE score of 2 and above.

\section{CNS cell isolation}

CNS mononuclear cells were isolated from EAE mice at different time points (non-immunized mice d0, peak disease $\mathrm{d} 14$, and at recovery phase $\mathrm{d} 24$ ) after cardiac perfusion with PBS. Briefly, minced CNS (spinal cord and brain) tissues were digested with collagenase $\mathrm{D}(2.5 \mathrm{mg} /$ $\mathrm{ml}$; Roche Diagnostics, Indianapolis, IN) at $37^{\circ} \mathrm{C}$ for 60 $\mathrm{min}$. Mononuclear cells were isolated by discontinuous Percoll gradient (70/30\%) (Sigma-Aldrich) centrifugation. Lymphocytes were collected from the 30:70\% interface and washed. Total cell numbers were determined by 
counting on a hemocytometer, and viability was assessed by trypan blue exclusion. To exclude the possibility of generating artifacts during the isolation process of CNSinfiltrating cells, the percentages rather than the "absolute" cell numbers were displayed to facilitate comparison of results.

\section{Flow cytometric analysis}

Single-cell suspensions from spleens, lymph nodes, and CNS from d0, d14, and d24 were incubated in blocking solution (PBS with $1 \%$ fetal calf serum) for $20 \mathrm{~min}$ on ice prior to staining to block nonspecific Fc-mediated interactions. They then were stained for $30 \mathrm{~min}$ at $4{ }^{\circ} \mathrm{C}$ with FITC, $\mathrm{PE}$, PerCP-Cy5, or allophycocyanin fluorochromes conjugated with antibodies (Abs; 1:100) against CD3, CD8, CD45, c-Met, CD44, CD62L, or appropriate fluorochromeconjugated, isotype-matched irrelevant Abs to establish background fluorescence. For intracellular cytokine and molecular staining of IFN $\gamma$, tumor necrosis factor (TNF), granzyme B, Eomes, Runx3, and Ki67 (see Table 1), T cells were stimulated with PMA $(50 \mathrm{ng} / \mathrm{ml})$ plus ionomycin (500 $\mathrm{ng} / \mathrm{ml})$ in the presence of brefeldin A $(10 \mu \mathrm{g} / \mathrm{ml}$; SigmaAldrich) and then fixed and permeabilized using BD Cytofix/Cytoperm Plus Kit (BD Biosciences). Samples were processed on a FACS Gallios flow cytometer (BD Biosciences) and analyzed using FlowJo analysis software (version 10.3). Live, apoptotic, and dead populations were defined on the basis of 7-AAD Viability Staining Solution from eBioscience according to the manufacturer's instructions. To determine the viability of cells prior to the fixation and permeabilization, we used the LIVE/DEAD ${ }^{\mathrm{m}}$ Fixable Aqua Dead Cell Stain Kit (Thermo Fisher Scientific).

\section{Preparation and treatment of splenic and $\mathrm{LN} \mathrm{CD8}{ }^{+} \mathrm{T}$ cells ex vivo}

For bulk cultures, single-cell suspensions were prepared from spleens of EAE mice (at peak disease d14). Briefly,

Table 1 Antibodies for flow cytometry

\begin{tabular}{lll}
\hline Specificity & Clone & Supplier \\
\hline CD45R & RA3-6B2 & eBioscience \\
CD3 & UCHT1 & Biolegend \\
CD8 & $53-6.7$ & eBioscience \\
CD44 & IM7 & eBioscience \\
CD62L & MEL-14 & eBioscience \\
c-Met & eBioclone7 & eBioscience \\
IFN-Y & XMG1.2 & eBioscience \\
Granzyme B & NGZB & eBioscience \\
TNF & MP6-XT22 & eBioscience \\
Eomes & Dan11mag & eBioscience \\
Runx3 & R3-5G4 & BD Biosciences \\
Ki67 & SolA15 & eBioscience \\
\hline
\end{tabular}

and LN were gently homogenized and passed through a $70-\mu \mathrm{m}$ nylon cell strainer (Falcon, BD Biosciences). Red blood cells were lysed with ACK lysing buffer (BioWhittaker). Mononuclear cell populations were counted, suspended in culture medium at $1 \times 10^{6}$ cells $/ \mathrm{ml}$, and then exposed to $\mathrm{mrHGF}(30 \mathrm{ng} / \mathrm{ml}$ ) or PBS (vehicle) for the same duration in the presence of adequate peptide $(20 \mu \mathrm{g} /$ $\mathrm{ml}$ of $\mathrm{MOG}_{35-55}$ or $\mathrm{MOG}_{37-50}$ or gp100 ${ }_{25-33}$ control peptide); IL-2 (20 pg/ml; PeproTech) was added to cultures for $48 \mathrm{~h}$ prior to performing FACS analysis. In some experiments, EAE spleen cells were harvested; stained at $4{ }^{\circ} \mathrm{C}$ for 30 min with CD3, CD8, and c-Met; and purified as $\mathrm{CD} 8^{+} \mathrm{c}-$ Met $^{-}$and $\mathrm{CD} 8^{+} \mathrm{C}-\mathrm{Met}^{+}$by cell sorting using a FACS Aria SORP II cell sorter (BD Biosciences). Live cells were gated based on forward scatter and side scatter and by DAPI dye exclusion. Sorted ex vivo c-Met ${ }^{-}$and $\mathrm{c}-\mathrm{Met}^{+} \mathrm{CD}^{+} \mathrm{T}$ cell populations showed similar physical properties of size and internal complexity. Sorted $\mathrm{CD}^{+} \mathrm{T}$ cells were incubated with irradiated syngeneic splenocytes loaded with $20 \mu \mathrm{g} / \mathrm{ml}$ $\left(\mathrm{MOG}_{35-55}, \mathrm{MOG}_{37-50}\right.$, or gp100 $25-33$ control peptide) for $48 \mathrm{~h}$ in the presence of $20 \mathrm{pg} / \mathrm{ml}$ of IL-2.

Human gp100 [33] is a fragment of human melanoma antigen gp100. The gp100-specific, H-2Db-restricted, $\mathrm{CD}^{+} \mathrm{T}$ cells are capable to recognize B16 melanoma but not normal melanocytes. Since this peptide is commonly used as an immunogen to test $\mathrm{CD}^{+} \mathrm{T}$ cellspecific response in several animal models [33], we decided to use this peptide as control.

\section{Measurement of effector molecules and cytokines}

Granzyme B, IFNY, and TNF levels were detected in culture supernatants from EAE (d14) T cells from the spleen and CNS and tissues using ELISA sets from eBioscience or R\&D Systems according to the respective manufacturer's instructions.

\section{Ex vivo cytotoxicity assay}

The in vitro killing activities of splenic $\mathrm{CD} 8^{+} \mathrm{T}$ cells obtained from $\mathrm{MOG}_{35-55}$-induced EAE (d14) stimulated ex vivo with $\mathrm{MOG}_{37-50}$ peptide were analyzed with a DELFIA $^{\circ}$ cell cytotoxicity kit (PerkinElmer), as previously described [35]. Briefly, target B lymphocytes (freshly isolated from the spleen of $\mathrm{B} 6$ mice) were pulsed with $10 \mu \mathrm{g} / \mathrm{ml}$ of $\mathrm{MOG}_{37-50}$ or control (gp100 $25-33$ ) peptide for $1 \mathrm{~h}$ at $37^{\circ} \mathrm{C}$ in culture medium. After three washes, Ag-pulsed cells were labeled $\left(1 \times 10^{6}\right.$ cells $\left./ \mathrm{ml}\right)$ with $50 \mu \mathrm{M}$ of fluorescence-enhancing ligand bis(acetoxymethyl) $2,2^{\prime}: 6^{\prime}, 2^{\prime \prime}$-terpyridine-t, $6^{\prime \prime}$ dicarboxylate for 30 min at $37^{\circ} \mathrm{C}$. Following an additional series of washes, labeled Ag-pulsed B cells were co-cultured in $200 \mu \mathrm{l}$ of medium at $5 \times 10^{3}$ cell/well in 96-well flat-bottom plates with (c-Met ${ }^{+}$vs. c-Met $\left.{ }^{-}\right) \mathrm{CD}^{+}{ }^{+} \mathrm{T}$ cells treated or not with HGF $(30 \mathrm{ng} / \mathrm{ml})$ at the indicated ratio. Plates were incubated for $4 \mathrm{~h}$ at $37^{\circ} \mathrm{C}$. After $4 \mathrm{~h}, 20 \mu \mathrm{l}$ of culture supernatant 
was harvested from each well and added to separate 96well flat-bottom plates containing $200 \mu \mathrm{l} /$ well of $50 \mu \mathrm{M}$ Europium solution (Aldrich Chemical) in $0.3 \mathrm{M}$ acetic acid ( $\mathrm{pH} 4)$. Plates were shaken for $15 \mathrm{~min}$ at room temperature, and the fluorescence of the Europium TDA (Eu) chelates formed was quantified in a timeresolved fluorometer (DELFIA 1234). All assays were performed in triplicate. Spontaneous release was determined as Eu detected in the supernatant of targets incubated in the absence of effector cells. Maximum release was determined as Eu detected in the supernatants of target cells incubated with lysis buffer instead of effectors. Percent specific lysis was calculated according to the following formula: (experimental release - spontaneous release) $/($ maximum release - spontaneous release $) \times$ 100

\section{Immunofluorescence}

Cytospin spleen cells from peak disease of EAE mice (d14) were fixed with acetone. Slides were blocked for 30 min in PBS with $1 \%$ bovine serum albumin. Abs against mouse c-Met (clone; eBioclone7, eBioscience) and CD8 (clone; 53-6.7, eBioscience) were applied at 1: 100. Sections were incubated overnight with both Abs, followed by several washes with PBS. Slides were mounted with ProLong Gold anti-fade reagent with DAPI (Life Technologies) and kept at $4{ }^{\circ} \mathrm{C}$. The slides were imaged by a core facility using a Leica SP5 Axiocam system (Leica MicroImaging).

\section{RNA isolation and real-time quantitative PCR}

RNA was prepared from MACS-sorted splenic $\mathrm{CD}^{+} \mathrm{T}$ cells at peak disease (d14) followed by separation with FACS Aria on c-Met ${ }^{+} \mathrm{CD} 8^{+}$or c-Met ${ }^{-} \mathrm{CD}^{+}$. Total RNA extractions were performed with the Qiagen RNeasy Mini Kit and subjected to DNase I (Roche Diagnostics) digestion. Random hexamer primers (Promega, Madison, WI) and Superscript II RNase $\mathrm{H}$ reverse transcriptase (Invitrogen, Carlsbad, CA) were used to generate cDNA. All transcripts were quantified by real-time PCR analysis using SYBR Green as the detection agent. The PCR was performed with the 7500 Real-Time PCR System (Applied Biosystems). The following primers were used: 5 ' to 3 ' forward GCGCATGTTTCCTTTCTTGAG and reverse GGTCGGCCAGAACCACTTC for EOMES; forward CAGGTTCAACGACCTTCGATT and reverse GTGGTAGGTAGCCACTTGGG for RUNX; forward AGCAAGGACGGCGAATGTT and reverse GGGTGG ACATATAAGCGGTTC for T-bet; forward CCCATC CCCAGGAGTCTTG and ACCATGACTAGGGG CACTGTA for GATA3; and forward CCCATC CCCAGGAGTCTTG and reverse ACCATGACTAGG GGCACTGTA for FOXP3. PCR was performed using the Taq Platinum polymerase kit (Thermo Fisher
Scientific). The amplification procedure included $3 \mathrm{~min}$ at $94{ }^{\circ} \mathrm{C}$ followed by 35 cycles of $30 \mathrm{~s}$ at $94{ }^{\circ} \mathrm{C}$ for denaturation, $30 \mathrm{~s}$ at $55^{\circ} \mathrm{C}$ for hybridization, and $1 \mathrm{~min}$ at $72{ }^{\circ} \mathrm{C}$ for elongation. A final $4 \mathrm{~min}$ at $72{ }^{\circ} \mathrm{C}$ was used for final elongation. PCR products were visualized on $1 \%$ agarose gel using Gelgreen (Ozyme) dye under ultraviolet illumination. Quantitative PCR was performed on a 7500 Real-Time PCR System with Power SYBR Green (Applied Biosystems).

\section{Statistical analysis}

Statistical calculations were performed using the statistical analysis software GraphPad Prism, version 7.0. Data were expressed as the mean \pm standard error mean (SEM), and the differences between groups were evaluated by unpaired Student's $t$ test. Intergroup comparisons were conducted by two-way analysis of variance (ANOVA) followed by Tukey's post hoc test to determine significant differences between experimental groups. $P$ values $<0.05$ were considered statistically significant.

\section{Results \\ A subpopulation of effector $\mathrm{CD}^{+} \mathrm{T}$ cells express the receptor c-Met in EAE}

Recent data indicate that $\mathrm{T}$ cell activation in the presence of HGF induces a distinct migratory phenotype [36]. Phenotypic and functional analysis of this newly identified CTL population (c-Met $\left.{ }^{+} \mathrm{CTLs}\right)$ showed that $\mathrm{c}-\mathrm{Met}^{+} \mathrm{CTLs}$ displayed augmented cytolytic activities compared to their c-Met ${ }^{-}$CTL counterparts in vitro and in vivo [33]. We hypothesized that the c-Met signature could directly regulate CD8 effector functions in CNS demyelination.

We first assessed the expression of c-Met during the course of $\mathrm{MOG}_{35-55}$-induced EAE. Mice were monitored for up to 24 days (recovery phase) post-immunization (Additional file 1: Figure S1A and B). No expression of c-Met was detected in resting naive $\mathrm{CD} 45^{+} \mathrm{CD} 8^{+} \mathrm{T}$ cells in the spleen, lymph node, or CNS (Fig. 1b). Remarkably, when compared to day 0 (pre-immunization), $\mathrm{CD}^{+} \mathrm{T}$ cells at peak disease (day 14 post-immunization) expressed significantly higher levels of c-Met receptor in the spleen and in the CNS compartment, as shown by c-Met ${ }^{+} \mathrm{CD}^{+}$frequencies and cell number graph (Fig. 1a, b). In addition, we observed an increase of c-Met ${ }^{+} \mathrm{CD} 8^{+} \mathrm{T}$ cell number (but not frequencies) in the LN at peak disease (versus day 0) (Fig. 1a, b). Furthermore, in examining expression of $\mathrm{T}$ cell activation markers at day 14 (peak disease), we found that $\mathrm{c}-\mathrm{Met}^{+} \mathrm{CD} 8^{+} \mathrm{T}$ cell levels of activation were increased $\left(\mathrm{CD} 44^{\text {high }} \mathrm{CD}^{-} 2 \mathrm{~L}^{-}\right)$when compared to their counterpart c-Met ${ }^{-} \mathrm{CD} 8^{+}$(Fig. 1c).

We next determined whether $\mathrm{CD}^{+} \mathrm{T}$ cells express cMet receptor. As shown by immunofluorescence, c-Met expression was observed in a significant proportion of $\mathrm{CD}^{+}$cells from EAE splenocytes at peak disease (day 14) (Fig. 1d). c-Met protein level was assessed by 


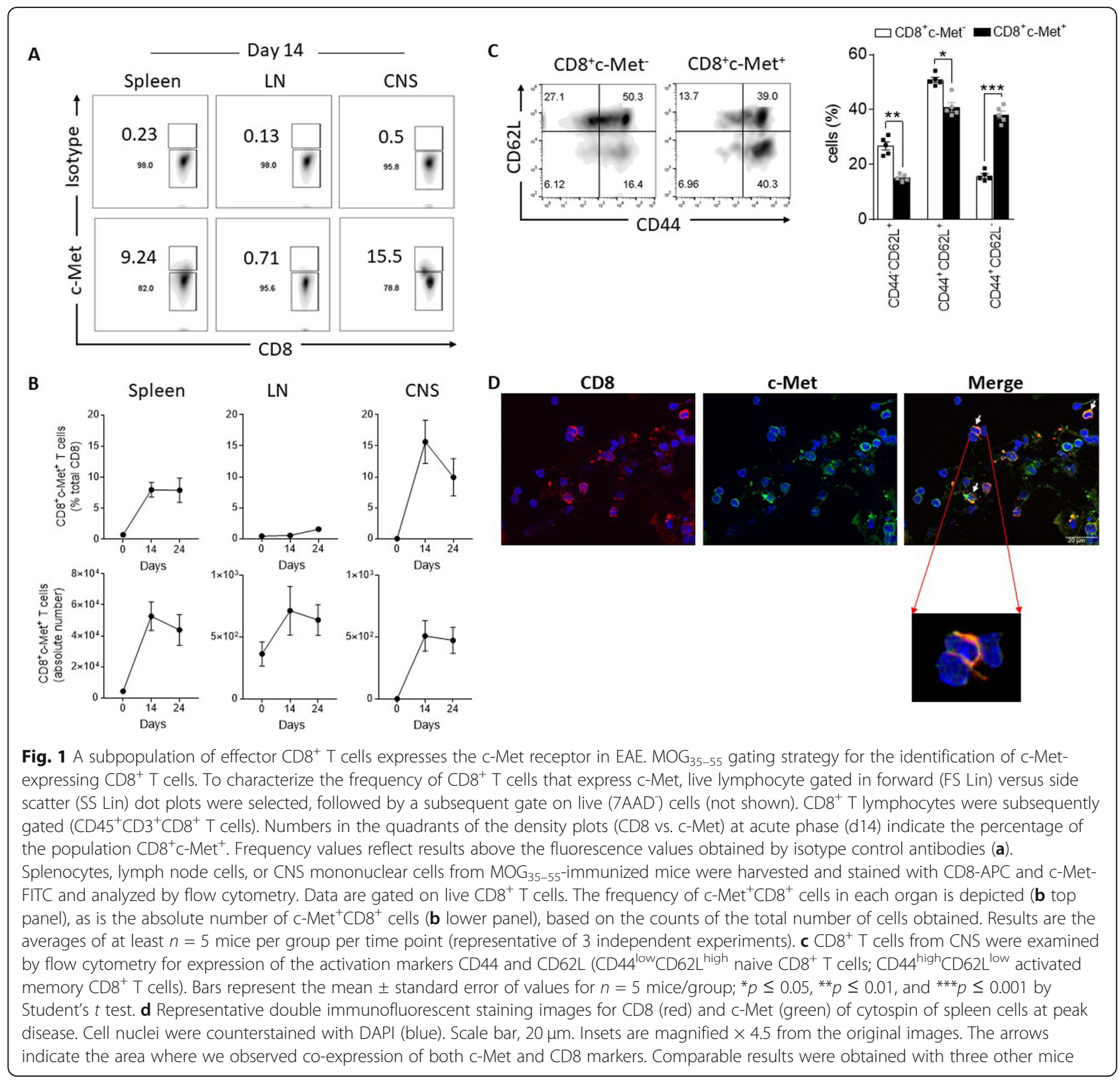

western blotting after splenic $\mathrm{CD}^{+} \mathrm{T}$ cells sorting (d14), and the results confirm the high expression of c-Met in FACS-sorted c- $\mathrm{Met}^{+} \mathrm{CD}^{+}{ }^{+} \mathrm{CD}^{+}{ }^{+}$(Additional file 1: Figure S1D). A weak c-Met expression was also observed in FACS-sorted c-Met ${ }^{-} \mathrm{CD}^{+}{ }^{+} \mathrm{CD}^{+}{ }^{+} \mathrm{T}$ cells that can be explained by intracellular c-Met expression.

\section{Phenotypic characterization of c-Met ${ }^{+} \mathrm{CD}^{+} \mathrm{T}$ cells ex vivo in MOG-induced EAE}

To evaluate $\mathrm{c}-\mathrm{Met}^{+} \mathrm{CD} 8^{+} \mathrm{T}$ cells in MOG-induced EAE, we analyzed recall $\mathrm{T}$ cell responses of $\mathrm{CD}^{+}$splenocytes from mice at peak disease (d14). Spleen cells were restimulated with either $\mathrm{MOG}_{35-55}, \mathrm{MOG}_{37-50}$, or gp100 ${ }_{25-}$ ${ }_{33}$ control peptide. We observed increased cell proliferation of c-Met ${ }^{+} \mathrm{CD}^{+} \mathrm{T}$ cells in the presence of both peptide $\mathrm{MOG}_{35-55}$ and $\mathrm{MOG}_{37-50}$ compared to their counterpart c-Met ${ }^{-} \mathrm{CD}^{+}$and the control condition (Fig. 2a, b).

\section{Increased granzyme $\mathrm{B}$ from c-Met ${ }^{+} \mathrm{CD}^{+}{ }^{\mathrm{T}}$ cells in EAE}

To characterize this population of CD8-expressing c-Met in MOG-induced EAE, we first isolated them from the spleen and the CNS at the peak disease (day 14). Cells were further co-cultured with irradiated syngeneic splenocytes loaded with $20 \mu \mathrm{g} / \mathrm{ml}\left(\mathrm{MOG}_{35-55}, \mathrm{MOG}_{37-50}\right.$, or gp100 $25-33$ ) for $48 \mathrm{~h}$ in the presence of $20 \mathrm{ng} / \mathrm{ml}$ of IL-2. After re-stimulation with $\mathrm{MOG}_{35-55}$, we observed no differ-

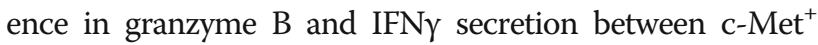
and c-Met ${ }^{-} \mathrm{CD}^{+} \mathrm{T}$ cells (Fig. 3a, b). Because $\mathrm{MOG}_{37-50^{-}}$ 


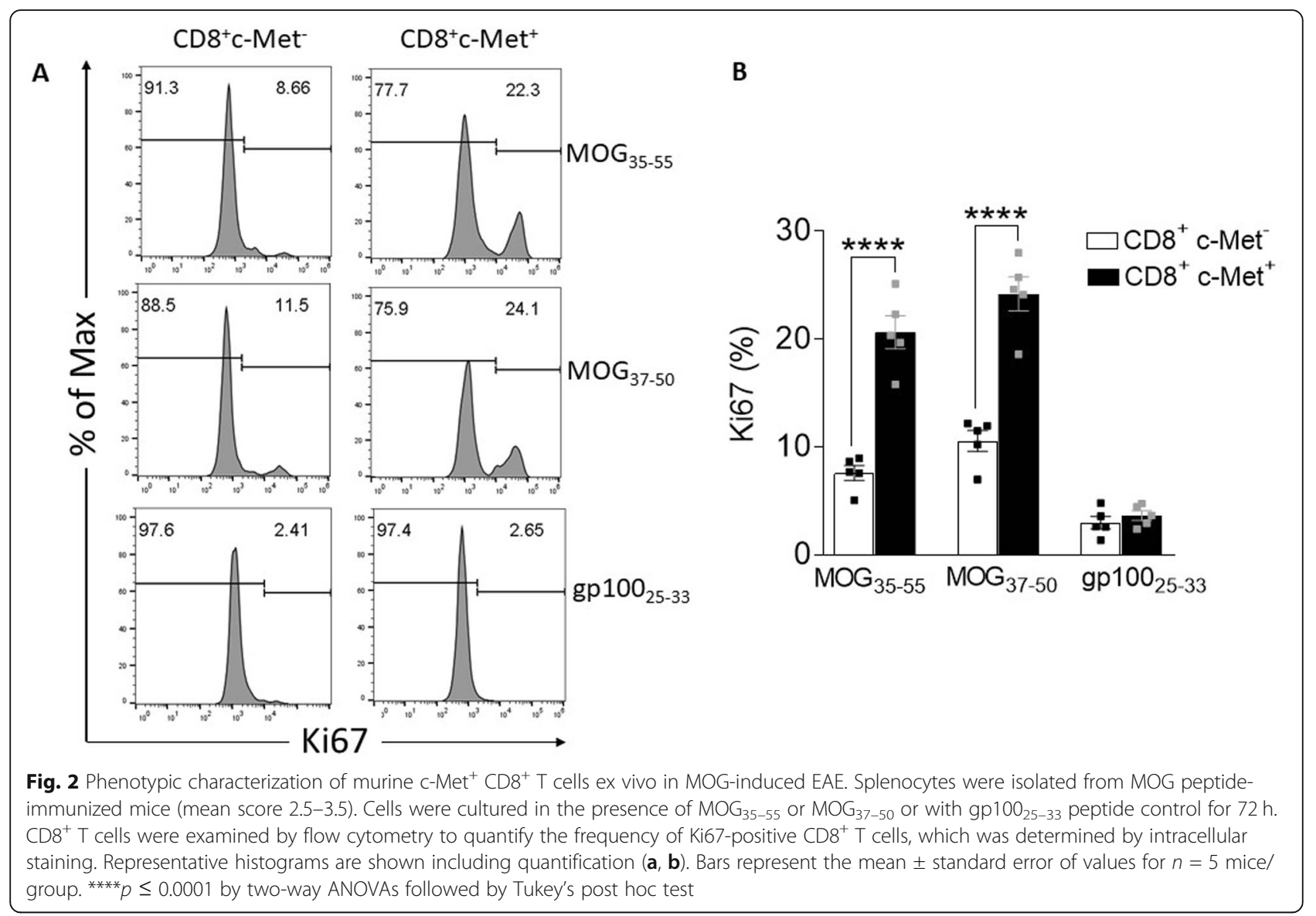

specific $\mathrm{CD}^{+} \mathrm{T}$ cells are generated in $\mathrm{MOG}_{35-55}$-induced EAE mice and $M \mathrm{G}_{37-50}$ peptide retains the full ability to stimulate MOG-specific $\mathrm{CD}^{+} \mathrm{T}$ cells ex vivo [14], we further examined the stimulation of c-Met ${ }^{+} \mathrm{CD}^{+} \mathrm{T}$ cells from both the spleen and CNS with $\mathrm{MOG}_{37-50}$ peptide. C$\mathrm{Met}^{+} \mathrm{CD}^{+} \mathrm{T}$ cells re-stimulated ex vivo with $\mathrm{MOG}_{37-50}$ peptide released significantly higher levels of granzyme in both the spleen and $\mathrm{CNS}$, and c-Met ${ }^{+} \mathrm{CD}^{+} \mathrm{T}$ cells from the CNS but not from the spleen released increased levels of IFNY (Fig. 3b). Finally, we found no difference in TNF secretion by either $\mathrm{CD}^{+} \mathrm{T}$ cell population (Met ${ }^{+}$vs Met-) in response to encephalitogenic peptides $\left(\mathrm{MOG}_{35-55}\right.$ or $\mathrm{MOG}_{37-50}$ ) (Fig. 3c). These data suggest that the $\mathrm{MOG}_{37-}$ 50 peptide generates $\mathrm{c}-\mathrm{Met}^{+} \mathrm{CD} 8^{+} \mathrm{T}$ cell-specific responses and increased granzyme $\mathrm{B}$ and IFNY release ex vivo in MOG-induced EAE.

\section{Expression modulation of $\mathrm{CD}^{+}$-specific lineage markers by HGF}

Our previous data indicated that cytotoxic $\mathrm{T}$ cells expressing c-Met (c-Met $\left.{ }^{+} \mathrm{CTLs}\right)$ are highly cytotoxic compared to their counterpart c-Met ${ }^{-}$CTLs [33], and another group showed that $\mathrm{T}$ cell activation in the presence of HGF induces a distinct migratory phenotype [36]. We hypothesized that c-Met protein expression in $\mathrm{CD}^{+} \mathrm{T}$ cells could directly regulate their gene and protein expression. To address this hypothesis, we first assessed the master regulator genes (RUNX3, EOMES, FOXP3, GATA3, and T-bet). mRNAs were extracted from sorted spleen c$\mathrm{Met}^{+}$vs. c-Met ${ }^{-} \mathrm{CD} 8^{+} \mathrm{T}$ cells at peak disease (d14) in MOG-induced EAE. RT-PCR data showed that c$\mathrm{Met}^{+} \mathrm{CD} 8^{+} \mathrm{T}$ cells expressed higher levels of RUNX3 and EOMES compared to c-Met ${ }^{-} \mathrm{CD}^{+}{ }^{+} \mathrm{T}$ cells; however, we observed no difference in the expression of Th1, Th2, or Treg-specific regulator genes such as T-bet, GATA3, and FOXP3, respectively (Fig. 4a). In flow cytometry assessment of Runx3 and Eomes protein expression, splenic c$\mathrm{Met}^{+} \mathrm{CD} 8^{+} \mathrm{T}$ cells expressed higher levels of Runx 3 and Eomes protein compared to c-Met ${ }^{-} \mathrm{CD}^{+} \mathrm{T}$ cells (Fig. 4b).

We next assessed the effects of HGF treatment on $\mathrm{CD}^{+} \mathrm{T}$ cells expressing c-Met receptor. Spleen cells from peak disease (d14) were treated with HGF (30 ng/ $\mathrm{ml}$ ) ex vivo for $48 \mathrm{~h}$ in the presence of IL-2. We found that HGF-treated c-Met ${ }^{+} \mathrm{CD} 8^{+} \mathrm{T}$ cells expressed significantly lower intracellular levels of Eomes and Runx3 protein compared with the untreated condition (Fig. 4c). As expected, HGF did not change the expression of Eomes and Runx3 in c-Met ${ }^{-} \mathrm{CD} 8^{+} \mathrm{T}$ cells (Fig. 4c). 
Spleen

A

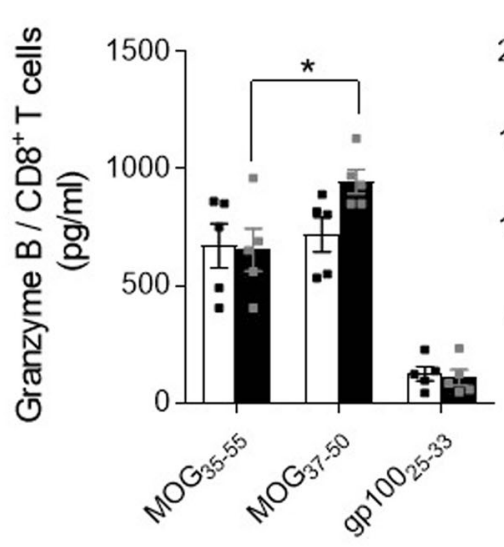

B

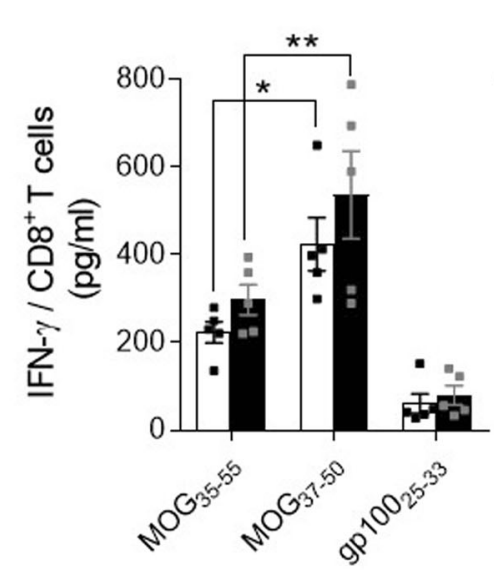

C

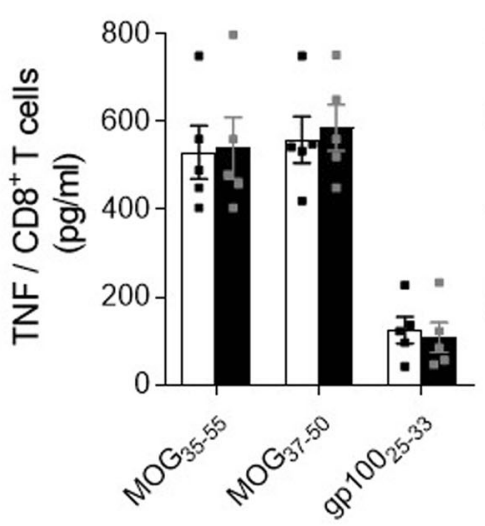

\section{CNS}

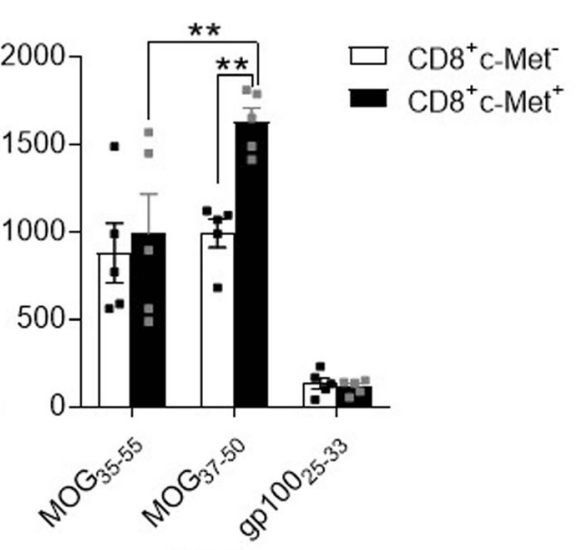

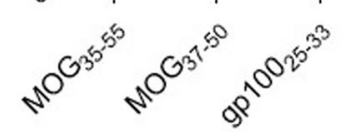

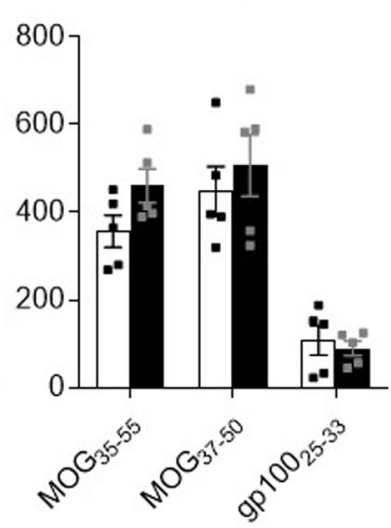

Fig. 3 Comparison of phenotype of CTLs located in the spleen and CNS in EAE. At day 14 post-EAE induction, CD8 T cells from the spleen and from CNS-infiltrating cells were isolated and incubated with irradiated syngeneic splenocytes loaded with $1 \mu \mathrm{M}$ of peptide $\left(\mathrm{MOG}_{35-55}, \mathrm{MOG}_{37-50}\right.$, or gp $100_{25-33}$ control peptide) for $48 \mathrm{~h}$ in the presence of $20 \mathrm{pg} / \mathrm{ml}$ IL-2. Granzyme B (a), IFNy (b), and TNF (c) levels were quantified by ELISA in the cell supernatant of stimulated inflammatory T cells. $n=5$ mice/group; data shown as mean \pm standard error. ${ }^{*} p \leq 0.05,{ }^{* *} p \leq 0.01,{ }^{* * * *} p \leq$ 0.0001 (two-way ANOVAs followed by Tukey's post hoc test)

Modulation of $\mathrm{C}-\mathrm{Met}^{+} \mathrm{CD} 8^{+} \mathrm{T}$ cell phenotype and function by HGF

We next assessed the effect of HGF treatment on ex vivo $\mathrm{c}-\mathrm{Met}^{+} \mathrm{CD}^{+} \mathrm{T}$ cells isolated at $\mathrm{d} 14$ from the spleen. $\mathrm{T}$ cells were stimulated with $\mathrm{MOG}_{37-50}$ peptide for $48 \mathrm{~h}$ before co-culture with the target cells loaded with the same peptide. HGF treatment significantly blunted the ex vivo cytotoxic function of $\mathrm{c}-\mathrm{Met}^{+} \mathrm{CD}{ }^{+} \mathrm{T}$ cells but had no effect on the killing ability of c$\mathrm{Met}^{-} \mathrm{CD}^{+}$(Fig. 5a). In addition, HGF treatment decreased the capacity of bulk (i.e., c-Met ${ }^{+}$and $\mathrm{c}-\mathrm{Met}^{-}$) $\mathrm{CD}^{+} \mathrm{T}$ cells isolated from the spleen of EAE mice to 


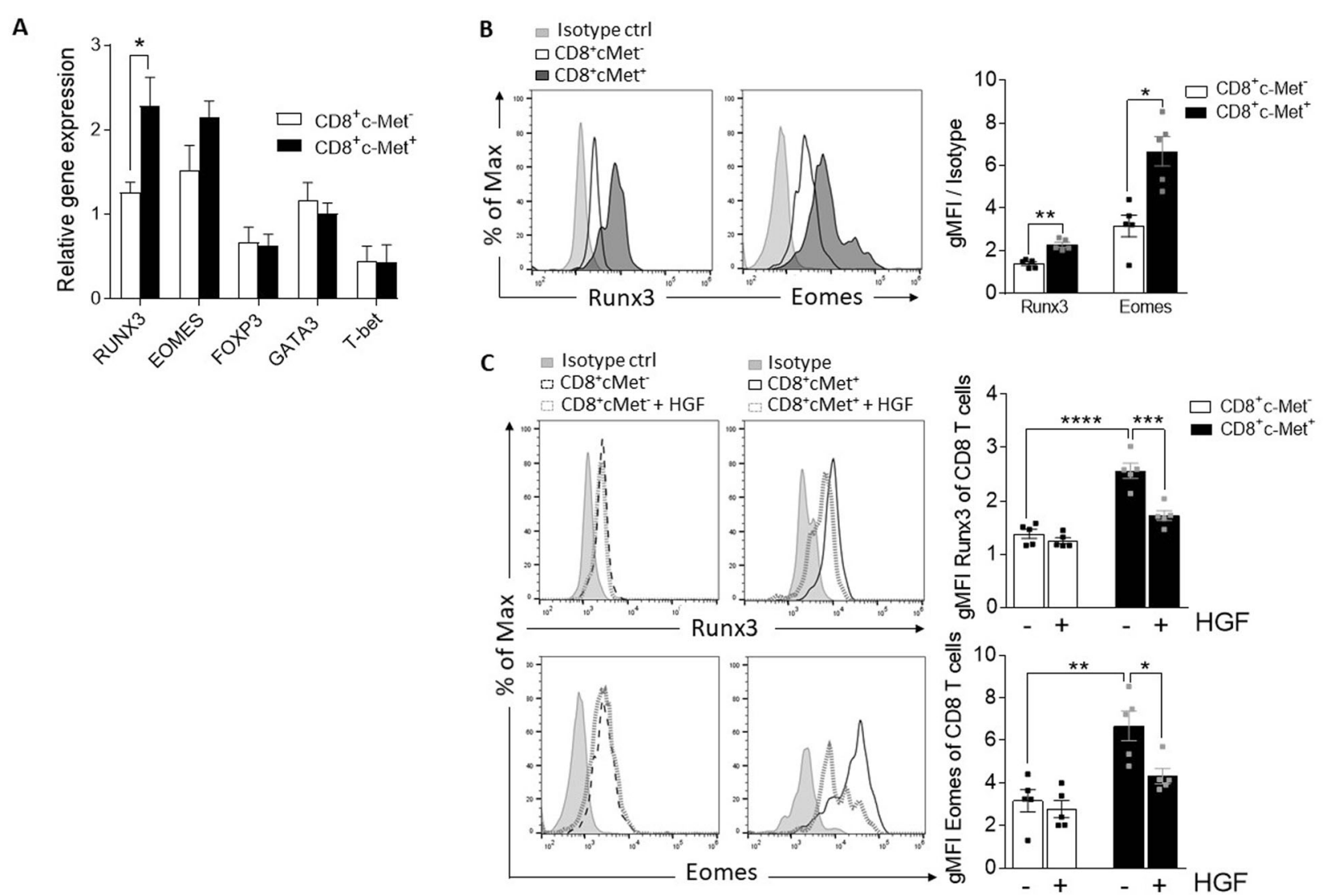

Fig. 4 Ex vivo gene and protein characterization of c-Met ${ }^{+}$versus c-Met ${ }^{-}$CD8 ${ }^{+} T$ cells. a Relative expression of EOMES, RUNX3, FOXP3, GATA3, and

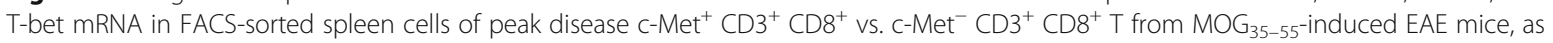
measured by quantitative RT-PCR, representative of $n=3$ mice; $* p \leq 0.05$ (unpaired, 2-tailed Student's $t$ test). b Representative histogram and average MFI (bar graph) of Runx3 and Eomes in EAE c-Met ${ }^{+}$vs. c-Met ${ }^{-} \mathrm{CD}^{+}{ }^{+} \mathrm{CD} 8^{+} \mathrm{T}$ cells, representative of $n=5$ mice. $\mathbf{c}$ Eomes and Runx3 protein levels in spleen cells at peak disease (d14) c-Met ${ }^{+} \mathrm{CD} 8^{+}$vs. C-Met ${ }^{-} \mathrm{CD} 8^{+} \mathrm{T}$ cells from MOG-induced EAE mice treated with either vehicle or HGF $(30 \mathrm{ng} / \mathrm{ml}$ for $48 \mathrm{~h}$ ) in the presence of IL-2; representative histograms are shown. Measurement of Eomes and Runx3 gMFI compared to isotype control of each condition (b, c). Data are representative of $n=5$ mice. ${ }^{*} p \leq 0.05,{ }^{* *} p \leq 0.01$ (unpaired, 2-tailed Student's $t$ test for $\mathbf{b}$ ). Data from $\mathbf{c}$ are presented as mean \pm SEM and were analyzed using the two-way ANOVA followed by Tukey post hoc comparisons. ${ }^{*} p \leq 0.05,{ }^{* *} p \leq$ $0.01,{ }^{* * *} p \leq 0.001,{ }^{* * * *} p \leq 0.0001$

produce granzyme B (Fig. 5b) and weak decrease of IFN $\gamma$, though not significant (Fig. 5c). As expected, HGF treatment did not change the expression profile of cytotoxic effector molecules in $\mathrm{c}-\mathrm{Met}^{-} \mathrm{CD} 8^{+} \mathrm{T}$ cells (Fig. $5 \mathrm{~b}$, c). Taken together, these results show that HGF downmodulates the cytolytic function of $\mathrm{c}^{-\mathrm{Met}^{+}} \mathrm{CTLs}$ through regulation of cytotoxic effector molecule expression such as granzyme B. These findings are in agreement with our previous data [33].

\section{Discussion}

HGF acts by binding to the HGF tyrosine kinase receptor, c-Met [37]. Both are expressed in brain-resident cells including neurons [38], mature oligodendrocytes [39, 40], oligodendrocyte progenitor cells [41,42], and microglia [43]. In addition to its neuroprotective effect, HGF blunts inflammation in a variety of inflammatory $\mathrm{T}$ cell-mediated disease models, suggesting that it suppresses a common inflammatory process. MOG-induced EAE is a model of MS mediated by encephalitogenic $\mathrm{CD} 4^{+} \mathrm{T}$ cell responses and characterized by demyelination and axonal loss [44]. We have previously demonstrated that overexpression of neuronal HGF attenuates disease progression in this model, partly via anti-inflammatory signals [26]. Using this MS model, we established that HGF exerts an antiinflammatory effect through the generation of tolerogenic dendritic cells and the subsequent suppression of autoreactive peripheral Th1 and Th17 cells, leading to reduced $\mathrm{CD}^{+} \mathrm{T}$ cell-mediated CNS injury. Whether HGF modulates cell-mediated immunity driven by MHC class Irestricted $\mathrm{CD}^{+} \mathrm{T}$ cells remained however unclear.

In addition, we recently demonstrated in an established model of murine CTL-mediated killing that HGF treatment decreases levels of effector CTL molecules 


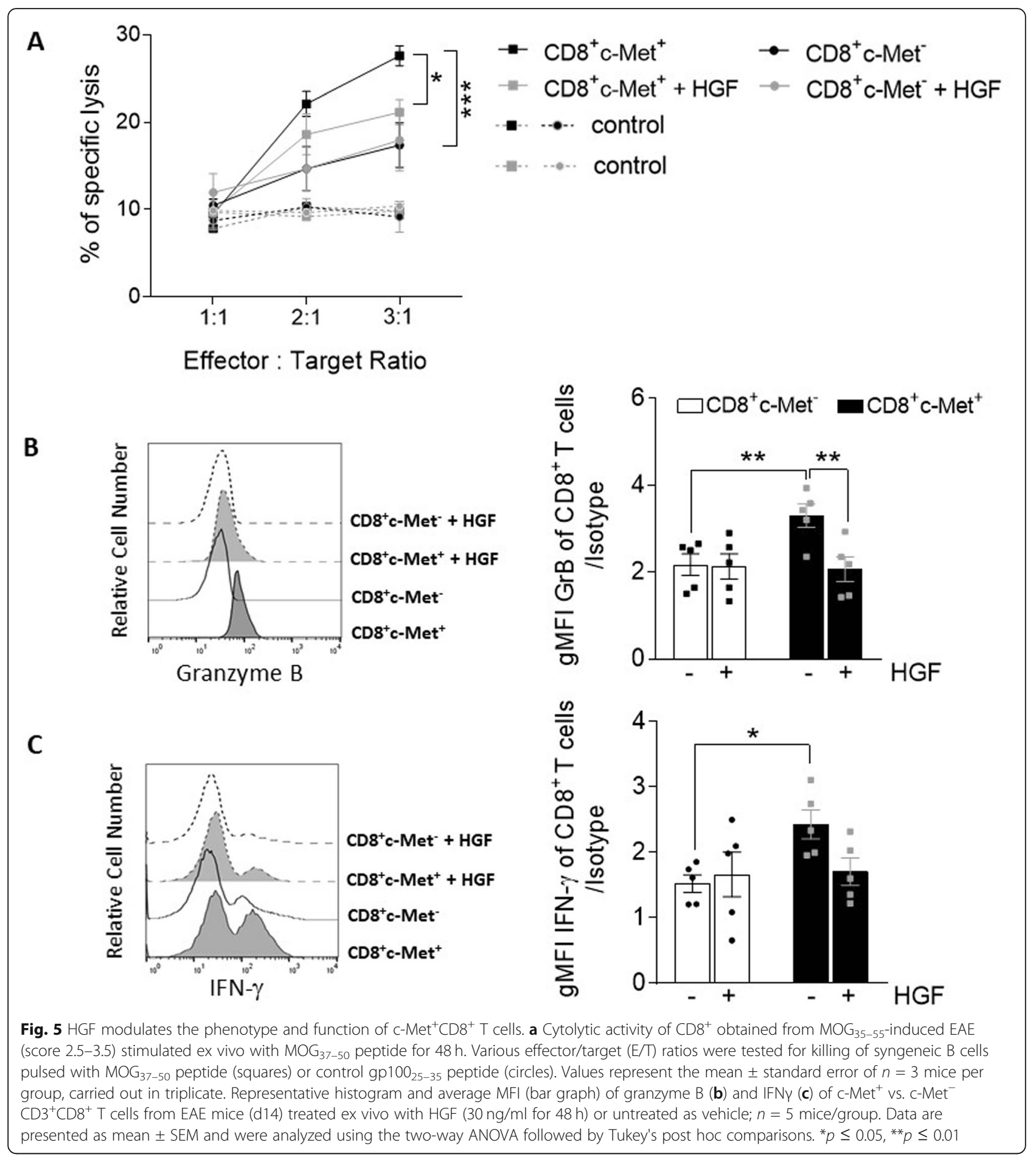

(IFN $\gamma$, TNF, perforin, granzyme B), as well as expression of CD107a, a marker of $\mathrm{CD}^{+} \mathrm{T}$ cell degranulation [35]. Based on these findings, we suggested that expression of c-Met on $\mathrm{CD}^{+} \mathrm{T}$ infiltrating cells may represent an additional pathway that limits the function of these $\mathrm{T}$ cells in the tumor microenvironment and ultimately favors tumor outgrowth [33].
Multiple observations support the idea that $\mathrm{CD}^{+} \mathrm{T}$ cells, in addition to pathogenic $\mathrm{CD}^{+} \mathrm{T}$ cells, are involved in the pathogenesis of CNS autoimmunity as active contributors to the development of neuroinflammation. In MS, $\mathrm{CD}^{+} \mathrm{T}$ cells outnumber by far $\mathrm{CD}^{+} \mathrm{T}$ cells in both acute and chronic inflammatory lesions. In CNS, although $\mathrm{CD}^{+} \mathrm{T}$ cells show a primarily 
perivascular distribution, $\mathrm{CD}^{+} \mathrm{T}$ cells can be detected in the parenchyma $[1,2]$. Although normally poorly expressed, MHC class I molecules are highly expressed within the MS lesion on astrocytes, oligodendrocytes, and neurons, suggesting that $\mathrm{CD} 8^{+} \mathrm{T}$ cells could be directly engaging these cell types $[45,46]$.

In this report, with the widely used $\mathrm{MOG}_{35-55} \mathrm{EAE}$ mouse model of MS, we demonstrate that a subgroup of the encephalitogenic $\mathrm{CD}^{+} \mathrm{T}$ cell population expresses c-Met receptor. This c-Met ${ }^{+} \mathrm{CD}^{+}{ }^{+} \mathrm{T}$ cell population significantly increased at the time of peak clinical disease and decreased in the recovery phase, similarly to the en-

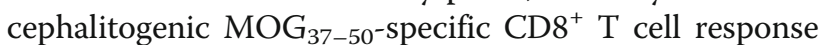
during EAE [14]. These $\mathrm{c}-\mathrm{Met}^{+} \mathrm{CD}^{+} \mathrm{T}$ cells have a higher level of activation compared to $\mathrm{c}-\mathrm{Met}^{-} \mathrm{CD} 8^{+} \mathrm{T}$ cells, which agrees with our previous observations related to murine c-Met ${ }^{+}$CTLs $[33,35]$. Using ex vivo and

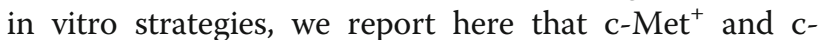
Met-CD8 ${ }^{+} \mathrm{T}$ cells in MOG-induced EAE exhibit a different functional phenotype and that HGF treatment downregulates the effector functions of c-Met ${ }^{+} \mathrm{CD}^{+} \mathrm{T}$ cells, as described in our previous studies [33, 35]. We have shown the capacity of HGF to reduce the encephalitogenic property of this subset of CTLs and suggest that expression of c-Met in $\mathrm{CD}^{+} \mathrm{T}$ cells may have a role in the causality of CNS pathology.

Our results are consistent with those of others demonstrating pathogenic potential of effector $\mathrm{CD}^{+} \mathrm{T}$ cells in a myelin basic protein model of EAE in $\mathrm{C} 3 \mathrm{HeB}$ mice [9]. The in vitro killing assay revealed a higher capacity of EAE-isolated $\mathrm{c}-\mathrm{Met}^{+} \mathrm{CD} 8^{+} \mathrm{T}$ cells to lyse their specific target cells compared to c-Met ${ }^{-} \mathrm{CD}^{+}{ }^{+} \mathrm{T}$ cells. These data are in line with findings on oligodendrocyte-specific autoreactive $\mathrm{CD}^{+} \mathrm{T}$ cells that can lyse oligodendrocytes in vitro [17]. $\mathrm{CD}^{+} \mathrm{T}$ cells induce demyelination through secretion of cytolytic factors, such as granzyme B, IFN $\gamma$, and lymphotoxin [16-18]. These data support our current results showing that $\mathrm{c}-\mathrm{Met}^{+} \mathrm{CD}^{+} \mathrm{T}$ cells produce a relatively higher level of granzyme $\mathrm{B}$ and IFNY. The implication of these observations is that expression of c-Met on $\mathrm{CD}^{+} \mathrm{T}$ cells in EAE may represent an additional pathway that explains the function of these $\mathrm{T}$ cells in the neuroinflammation microenvironment, ultimately favoring disease aggravation.

We found that HGF potently inhibits c-Met ${ }^{+} \mathrm{CD}^{+} \mathrm{T}$ cell-mediated killing through interference with decreases in granzyme B and IFN $\gamma$, suggestive of a direct effect of HGF on dual granzyme $\mathrm{B} / \mathrm{IFN} \gamma$-based CTL-mediated cytotoxicity. Because the perforin/granzyme B pathway has been implicated in potential mechanisms of oligodendrocyte and/or axonal injury and demyelination in MS [7], our findings together suggest that increased HGF may reduce CTL effector function in CTLmediated human autoimmune disorders of the CNS.
Important unanswered questions now arise from the current findings including which mechanisms are involved in the generation of $\mathrm{c}-\mathrm{Met}^{+} \mathrm{CD}^{+} \mathrm{T}$ cells and how does HGF regulate this new population? The demonstration of the inhibitory effect of HGF should be further confirmed with c-Met blocker experiments. In addition, our data indicate that although c-Met expression is undetectable in naive $\mathrm{CD}^{+} \mathrm{T}$ cells in non-immunized mice, it characterizes a significant proportion of $\mathrm{CD}^{+} \mathrm{T}$ cells at peak disease and remains during the recovery phase. This pattern suggests that the population of $\mathrm{c}-\mathrm{Met}^{+} \mathrm{CD} 8^{+} \mathrm{T}$ cells arise from pathologic changes associated with EAE development, as shown in tumor studies [33].

\section{Conclusions}

Our findings highlight the role of $\mathrm{CD}^{+} \mathrm{T}$ cell subpopulation expressing the c-Met receptor in a model of CNS autoimmunity. HGF may thus be effective in preventing inflammatory neurodegenerative disease via its immunosuppressive role on $\mathrm{CD}^{+} \mathrm{T}$ cells. Further studies in both EAE animal models and in MS are needed to provide a better understanding of the role of the HGF/c-Met axis in modulation of neuroinflammation.

\section{Supplementary information}

Supplementary information accompanies this paper at https://doi.org/10. 1186/s12974-019-1676-0.

Additional file 1: Figure S1. MOG-induced EAE clinical score. (A) $\mathrm{MOG}_{35-55}$ induces EAE in B6 mice. EAE was induced by immunization with $200 \mu \mathrm{g}$ of $\mathrm{MOG}_{35-55}$, emulsified in CFA on days 0 . Mice also received $300 \mathrm{ng}$ of pertussis toxin intravenously on days 0 and 2. EAE disease severity was followed, and incidence is shown in (B). (C) The forward scatter of both populations' c-Met ${ }^{+}$vs c-Met ${ }^{-}$CD8 ${ }^{+}$cells are represented. (D) Protein expression levels of c-Met by $C D 8^{+} \mathrm{T}$ cells in EAE at day 14. Lines 1, 2, 3 correspond respectively to: 1) bulk splenic CD $8^{+}$T cells enriched by negative selection using $\mu$ beads, 2) FACS-sorted (EAE d14) c$\mathrm{Met}^{+} \mathrm{CD}^{+}{ }^{+} \mathrm{CD}^{+} \mathrm{T}$ cells and 3 ) FACS-sorted (EAE d14) $\mathrm{c}^{-\mathrm{Met}^{-} \mathrm{CD} 3^{+} \mathrm{CD}^{+} \mathrm{T}}$ cells, as measured by Western blot ( $n=3$ mice). Purified CD8+ T cells were homogenized using a polytron in lysis buffer (50 mM Tris- $\mathrm{HCl}[\mathrm{pH} 7.5]$, $250 \mathrm{mM} \mathrm{NaCl}, 1 \%$ Triton X-100, 1 mM EDTA, and $1 \mathrm{mM}$ DTT) containing complete protease inhibitors (Roche). Equal amounts $(20 \mu \mathrm{g})$ of total protein from each sample were transferred to a $15 \%$ sodium dodecyl sulfate (SDS)-polyacrylamide gel and blotted onto anlmmobilon-P polyvinylidene difluoride (PVDF) membrane (Millipore). Expression levels of c-Met were detected using properly diluted $(1: 100)$ mouse monoclonal anti-cMet Ab (clone 3i20,Abcam), followed by a peroxidase-conjugated secondary Ab to mouse IgG1 (eBioscience), and then visualized using chemiluminescence (Supersignal; Pierce). The blot was also probed with mouse monoclonal anti- $\beta$-actine (clone 15G5A11/E2) as a loading control (Sigma-Aldrich).

\section{Abbreviations}

CFA: Complete Freund's adjuvant; CNS: Central nervous system; CTL: Cytotoxic T lymphocytes; EAE: Experimental autoimmune encephalomyelitis; EOMES: Eomesodermin; FOXP3: Forkhead box P3; GATA3: Trans-acting T cell-specific transcription factor; HGF: Hepatocyte growth factor; i.p: Intraperitoneal; i.v: Intravenous; IFN: Interferon; LN: Lymph node; MOG: Myelin oligodendrocyte glycoprotein; MS: Multiple sclerosis; PMA: Phorbol myristate acetate; RUNX3: Runt-related transcription factor 3; T- 
bet: T-box transcription factor; Th: T helper; TNF: Tumor necrosis factor; Treg: T regulatory

\section{Acknowledgements}

We thank Catherine Juillard and Mannekomba Roxane Diagbouga for technical help.

\section{Authors' contributions}

MB designed and performed the experiments, collected and analyzed data, and drafted the manuscript. IS contributed to the experimental design and revised the manuscript. PHL designed and supervised the study and drafted and critically revised the manuscript. All authors read and approved the final manuscript.

\section{Funding}

This work was supported by grants from the Swiss National Science Foundation (SNSF_310030_176078) and the Swiss Multiple Sclerosis Society.

\section{Availability of data and materials}

The datasets used and/or analyzed during the current study are available from the corresponding author on reasonable request.

\section{Ethics approval and consent to participate}

Animals were housed in a specific pathogen-free barrier facility at the Medical Center of Geneva, Faculty of Medicine (Geneva, Switzerland). All experimental protocols and procedures were reviewed and approved by the Institutional Animal Care and Use Committee of the Geneva University School of Medicine. Animal care and experimental procedures were carried out in accordance with the guidelines of the Institutional Animal Care and Use Committee of the Geneva University School of Medicine.

\section{Consent for publication}

All authors agree to the publication of this manuscript.

\section{Competing interests}

The authors declare that they have no competing interests.

Received: 26 September 2019 Accepted: 16 December 2019 Published online: 19 February 2020

\section{References}

1. Booss J, Esiri MM, Tourtellotte WW, Mason DY. Immunohistological analysis of T lymphocyte subsets in the central nervous system in chronic progressive multiple sclerosis. J Neurol Sci. 1983;62(1-3):219-32.

2. Hauser SL, et al. Immunohistochemical analysis of the cellular infiltrate in multiple sclerosis lesions. Ann Neurol. 1986;19(6):578-87.

3. Salou M, et al. Expanded CD8 T-cell sharing between periphery and CNS in multiple sclerosis. Ann Clin Transl Neurol. 2015;2(6):609-22.

4. Babbe $\mathrm{H}$, et al. Clonal expansions of CD8(+) T cells dominate the $\mathrm{T}$ cell infiltrate in active multiple sclerosis lesions as shown by micromanipulation and single cell polymerase chain reaction. J Exp Med. 2000;192(3):393-404.

5. Junker A, et al. Multiple sclerosis: T-cell receptor expression in distinct brain regions. Brain. 2007:130(Pt 11):2789-99.

6. Skulina C, et al. Multiple sclerosis: brain-infiltrating CD8+ T cells persist as clonal expansions in the cerebrospinal fluid and blood. Proc Natl Acad Sci U S A. 2004;101(8):2428-33.

7. Neumann H, Medana IM, Bauer J, Lassmann H. Cytotoxic T lymphocytes in autoimmune and degenerative CNS diseases. Trends Neurosci. 2002;25(6): 313-9.

8. Saikali P, et al. NKG2D-mediated cytotoxicity toward oligodendrocytes suggests a mechanism for tissue injury in multiple sclerosis. J Neurosci. 2007;27(5):1220-8.

9. Huseby ES, et al. A pathogenic role for myelin-specific CD8(+) T cells in a model for multiple sclerosis. J Exp Med. 2001;194(5):669-76.

10. Sun $D$, et al. Myelin antigen-specific CD8+ T cells are encephalitogenic and produce severe disease in C57BL/6 mice. J Immunol. 2001;166(12):7579-87.

11. Cabarrocas J, Bauer J, Piaggio E, Liblau R, Lassmann H. Effective and selective immune surveillance of the brain by MHC class I-restricted cytotoxic T lymphocytes. Eur J Immunol. 2003;33(5):1174-82.
12. Zehntner SP, Brisebois M, Tran E, Owens T, Fournier S. Constitutive expression of a costimulatory ligand on antigen-presenting cells in the nervous system drives demyelinating disease. FASEB J. 2003;17(13):1910-2.

13. Saxena A, et al. Cutting edge: multiple sclerosis-like lesions induced by effector CD8 T cells recognizing a sequestered antigen on oligodendrocytes. J Immunol. 2008;181(3):1617-21.

14. Ford ML, Evavold BD. Specificity, magnitude, and kinetics of MOG-specific CD8+ T cell responses during experimental autoimmune encephalomyelitis. Eur J Immunol. 2005;35(1):76-85.

15. Willis $C M$, et al. Extracellular vesicle fibrinogen induces encephalitogenic CD8+ T cells in a mouse model of multiple sclerosis. Proc Natl Acad Sci U S A. 2019;116(21):10488-93.

16. Buckle GJ, Hollsberg P, Hafler DA. Activated CD8+ T cells in secondary progressive MS secrete lymphotoxin. Neurology. 2003;60(4):702-5

17. Jewtoukoff $\mathrm{V}$, Lebar R, Bach MA. Oligodendrocyte-specific autoreactive $T$ cells using an alpha/beta T-cell receptor kill their target without self restriction. Proc Natl Acad Sci U S A. 1989:86(8):2824-8.

18. Ifergan I, et al. Central nervous system recruitment of effector memory CD8+ T lymphocytes during neuroinflammation is dependent on alpha4 integrin. Brain. 2011;134(Pt 12):3560-77.

19. Kashi VP, Ortega SB, Karandikar NJ. Neuroantigen-specific autoregulatory CD8+ T cells inhibit autoimmune demyelination through modulation of dendritic cell function. PLoS One. 2014:9(8):e105763.

20. Ortega SB, et al. The disease-ameliorating function of autoregulatory CD8 T cells is mediated by targeting of encephalitogenic CD4 T cells in experimental autoimmune encephalomyelitis. J Immunol. 2013:191(1):117-26.

21. Jiang $H$, Braunstein NS, Yu B, Winchester R, Chess L. CD8+ T cells control the TH phenotype of MBP-reactive CD4+ T cells in EAE mice. Proc Natl Acad Sci U S A. 2001;98(11):6301-6

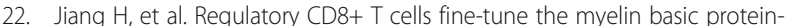
reactive $T$ cell receptor $V$ beta repertoire during experimental autoimmune encephalomyelitis. Proc Natl Acad Sci U S A. 2003;100(14):8378-83.

23. York NR, et al. Immune regulatory CNS-reactive CD8+T cells in experimental autoimmune encephalomyelitis. J Autoimmun. 2010;35(1):33-44.

24. Chen ML, Yan BS, Kozoriz D, Weiner HL. Novel CD8+ Treg suppress EAE by TGF-beta- and IFN-gamma-dependent mechanisms. Eur J Immunol. 2009; 39(12):3423-35.

25. Molnarfi N, Benkhoucha M, Funakoshi H, Nakamura T, Lalive PH. Hepatocyte growth factor: a regulator of inflammation and autoimmunity. Autoimmun Rev. 2014.

26. Benkhoucha M, et al. Hepatocyte growth factor inhibits CNS autoimmunity by inducing tolerogenic dendritic cells and CD25+Foxp3+ regulatory T cells. Proc Natl Acad Sci U S A. 2010:107(14):6424-9.

27. Bai L, et al. Hepatocyte growth factor mediates mesenchymal stem cellinduced recovery in multiple sclerosis models. Nat Neurosci. 2012;15:862-79.

28. Okunishi $\mathrm{K}$, et al. A novel role of hepatocyte growth factor as an immune regulator through suppressing dendritic cell function. J Immunol. 2005; 175(7):4745-53.

29. Futamatsu $\mathrm{H}$, et al. Hepatocyte growth factor ameliorates the progression of experimental autoimmune myocarditis: a potential role for induction of $\mathrm{T}$ helper 2 cytokines. Circ Res. 2005;96(8):823-30.

30. Rutella $\mathrm{S}$, et al. Hepatocyte growth factor favors monocyte differentiation into regulatory interleukin (IL)-10++|L-12low/neg accessory cells with dendritic-cell features. Blood. 2006;108(1):218-27.

31. Molnarfi N, Benkhoucha M, Juillard C, Bjarnadottir K, Lalive PH. The neurotrophic hepatocyte growth factor induces protolerogenic human dendritic cells. J Neuroimmunol. 2014;267(1-2):105-10.

32. Yen BL, et al. Multipotent human mesenchymal stromal cells mediate expansion of myeloid-derived suppressor cells via hepatocyte growth factor/c-Met and STAT3. Stem Cell Reports. 2013;1(2):139-51.

33. Benkhoucha $M$, et al. Identification of a novel population of highly cytotoxic c-Met-expressing CD8(+) T lymphocytes. EMBO Rep. 2017;18(9):1545-58.

34. Benkhoucha $M$, et al. Hepatocyte growth factor limits autoimmune neuroinflammation via glucocorticoid-induced leucine zipper expression in dendritic cells. J Immunol. 2014;193(6):2743-52.

35. Benkhoucha M, Molnarfi N, Schneiter G, Walker PR, Lalive PH. The neurotrophic hepatocyte growth factor attenuates CD8+ cytotoxic Tlymphocyte activity. J Neuroinflammation. 2013;10:154.

36. Komarowska I, et al. Hepatocyte growth factor receptor c-Met instructs T cell cardiotropism and promotes T cell migration to the heart via autocrine chemokine release. Immunity. 2015;42(6):1087-99. 
37. Bottaro DP, et al. Identification of the hepatocyte growth factor receptor as the c-met proto-oncogene product. Science. 1991;251(4995):802-4.

38. Maina F, Klein R. Hepatocyte growth factor, a versatile signal for developing neurons. Nat Neurosci. 1999;2(3):213-7.

39. Kitamura $\mathrm{K}$, et al. Hepatocyte growth factor promotes endogenous repair and functional recovery after spinal cord injury. J Neurosci Res. 2007;85(11): 2332-42.

40. Ohya W, Funakoshi H, Kurosawa T, Nakamura T. Hepatocyte growth factor (HGF) promotes oligodendrocyte progenitor cell proliferation and inhibits its differentiation during postnatal development in the rat. Brain Res. 2007; 1147:51-65.

41. Lalive PH, et al. TGF-beta-treated microglia induce oligodendrocyte precursor cell chemotaxis through the HGF-c-Met pathway. Eur J Immunol. 2005;35(3):727-37.

42. Yan H, Rivkees SA. Hepatocyte growth factor stimulates the proliferation and migration of oligodendrocyte precursor cells. J Neurosci Res. 2002;69(5): 597-606.

43. Di Renzo MF, et al. Selective expression of the Met/HGF receptor in human central nervous system microglia. Oncogene. 1993;8(1):219-22.

44. Zamvil SS, Steinman L. The T lymphocyte in experimental allergic encephalomyelitis. Annu Rev Immunol. 1990;8:579-621.

45. Traugott U, Reinherz EL, Raine CS. Multiple sclerosis. Distribution of T cells, T cell subsets and la-positive macrophages in lesions of different ages. J Neuroimmunol. 1983:4(3):201-21.

46. Neumann H, Schmidt H, Cavalie A, Jenne D, Wekerle H. Major histocompatibility complex (MHC) class I gene expression in single neurons of the central nervous system: differential regulation by interferon (IFN)gamma and tumor necrosis factor (TNF)-alpha. J Exp Med. 1997;185(2):305-16.

\section{Publisher's Note}

Springer Nature remains neutral with regard to jurisdictional claims in published maps and institutional affiliations.

Ready to submit your research? Choose BMC and benefit from:

- fast, convenient online submission

- thorough peer review by experienced researchers in your field

- rapid publication on acceptance

- support for research data, including large and complex data types

- gold Open Access which fosters wider collaboration and increased citations

- maximum visibility for your research: over $100 \mathrm{M}$ website views per year

At $\mathrm{BMC}$, research is always in progress.

Learn more biomedcentral.com/submissions 